\title{
Chłoniak z komórek płaszcza - rola terapii celowanych
}

\section{Mantle cell lymphoma - the role of targeted therapies}

\section{Streszczenie}

Postępy w leczeniu chłoniaka z komórek płaszcza (mantle cell lymphoma - MCL) poprawiły całkowity czas przeżycia (overall survival - OS), jednak wyzwaniem pozostają postacie oporne/nawrotowe (relapsed/refractory - R/R), co warunkuje potrzebę pilnego rozwoju nowych możliwości terapeutycznych. Główne kierunki analiz to rozwój inhibitorów kinazy tyrozynowej Brutona, inhibitorów kinazy fosfatydyloinozytolu oraz inhibitorów BCL-2. Pojawiają się również obiecujące terapie obejmujące nowe przeciwciała monoklonalne oraz bispecyficzne, z zastosowaniem immunologicznych punktów końcowych oraz immunoterapii opartej na limfocytach T. Potencjalna synergia nowych metod leczenia stanowi obecnie główny nurt badań klinicznych.

\section{Abstract}

Advances in mantle cell lymphoma (MCL) therapy have improved overall survival (OS), but managing relapsed/refractory (R/R) cases remains the challenge, that determines the urgent need for the development of new therapeutic options. The new targeted agents in development include Bruton's tyrosine kinase inhibitors, phosphoinositide 3-kinase (PI3K) inhibitors and BCL-2 inhibitors. Emerging therapies also include novel immunotherapeutic regimens using immune checkpoint inhibitors and T-cell-based adoptive immunotherapy. The potential synergy of these new agents is currently being the main stream of clinical trials.
Article history:

Received: 29.07 .2019

Accepted: 02.08 .2019

Wojciech Jurczak Monika Długosz-Danecka*

Katedra i Klinika Hematologii, Uniwersytet Jagielloński Collegium Medicum w Krakowie, Polska

C) 2019 Polish Society of Hematology and Transfusion Medicine, Insitute of Hematology and Transfusion Medicine. Published by Sciendo. All rights reserved.

Słowa kluczowe:

chłoniak z komórek płaszcza, inhibitory kinaz, kinaza tyrozynowa Brutona, nawrót, terapia celowana Keywords:

Bruton's tyrosine kinase, kinase inhibitors, mantle cell lymphoma, relapse, targeted therapy
$\mathrm{Na}$ chłoniaka z komórek płaszcza (mantle cell lymphoma - MCL) zapada w Polsce blisko 400 osób rocznie. Pierwotnym zaburzeniem cytogenetycznym jest w zdecydowanej większości przypadków translokacja $t(11 ; 14)$ i związana $z$ nią nadekspresja cykliny D1. Są one przyczyną głębokich zaburzeń cyklu komórkowego, które stosunkowo szybko doprowadzają do powstania wtórnych zaburzeń cytogenetycznych warunkujących oporność na immunochemioterapię. Oznacza to konieczność przemyślanego postępowania, gdzie każda decyzja terapeutyczna ma ważne konsekwencje dla rokowania pacjenta [1-3].

Kliniczne czynniki ryzyka stały się podstawą opracowania międzynarodowego wskaźnika rokowniczego (MCL International Prognostic Index - MIPI) [4], który uzupełniony o odsetek komórek wykazujących ekspresję ki67 [5] jest obecnie najczęściej stosowanym czynnikiem prognostycznym. Oznaczenie ki67 jest w praktyce możliwe jedynie w preparatach z węzła chłonnego lub nacieków narządowych, stąd ich wyższość nad trepanobioptatem. Dla rokowania niekorzystne znaczenie ma również brak mutacji łańcucha ciężkiego immunoglobulin (immunoglobulin heavy chain - IgVH), ekspresja SOX-11 i stwierdzenie mutacji TP53 [6].

MCL wyróżnia się początkowo małą dynamiką kliniczną, przypominającą chłoniaki o indolentnym przebiegu. Wyodrębniono grupę chorych z MCL o korzystnym rokowaniu, którą charakteryzuje bezobjawowy przebieg kliniczny i brak powiększenia węzłów chłonnych. Pacjenci z tej grupy mają zwykle podwyższoną liczbę białych krwinek w badaniu morfologii, zajęcie szpiku, często również powiększenie śledziony. Wskaźnik MIPI jest niski, podobnie jak odsetek komórek z ekspresją ki67, są już one po etapie mutacji lgVH i brak jest wtórnych zaburzeń cytogenetycznych [7]. To grupa chorych, których można do czasu progresji poddać obserwacji, a w razie potrzeby leczenia zastosować monoterapię rytuksymabem lub mało intensywną immunochemioterapię.

$U$ pozostałych chorych podstawowe znaczenie dla podjęcia decyzji o wyborze leczenia I linii ma możliwość poddania ich wysokodawkowanej chemioterapii z następowym autologicznym przeszczepieniem komórek macierzystych (autologous stem cell transplantation ASCT). Retrospektywna ocena Polskiej Grupy Badawczej Chłoniaków (Polish Lymphoma Research Group - PLRG) wykazała, że można ją rozważać u $20 \%$ pacjentów [8]. Preferowane są w tej grupie schematy z pośrednimi dawkami cytarabiny, podawane zwykle na przemian ze schematami opierającymi się na antracyklinach (tzw. Protokół Nordycki, R-HyperCVAD/ R-MTX-Ara-C czy R-CHOP/R-DHAP) [9-11]. Większość chorych nie może być jednak poddana ASCT ze względu na ich starszy wiek, upośledzony stan czynnościowy organizmu lub choroby towarzyszące. Zaleca się w takich przypadkach alternatywne

* Corresponding author: Monika Długosz-Danecka, Katedra i Klinika Hematologii, Uniwersytet Jagielloński Collegium Medicum, ul. Kopernika 17, 31-501 Kraków, Tel. 12/4247600, 606979167, E-mail: monika.dlugosz-danecka@uj.edu.pl 
schematy immunochemioterapii, takie jak: R-CHOP, BR, VR-CAP czy R-BAC [12]. Każdego chorego z dobrą odpowiedzią na leczenie należy przez kolejne 2 lata poddać leczeniu podtrzymującemu rytuksymabem, by opóźnić wznowę chłoniaka [13, 14].

Inhibitory kinazy tyrozynowej Brutona (Bruton's tyrosine kinase BTK) doprowadziły do przełomu w leczeniu chorych z nawrotowym/ opornym na leczenie MCL (relapsed/refractory MCL - R/R MCL), stając się niezbędnym elementem standardu leczenia. Mają one mechanizm działania alternatywny do cytostatyków, niezależny od apoptozy komórki, przez co mogą przełamać oporność na immunochemioterapię. Przerywając przekazywanie sygnału z receptora limfocytu $B$, wygaszają aktywność kinazy białkowej $C$ (PRKCB), a przez to hamują jądrowy czynnik transkrypcyjny NF kappa $\mathrm{B}$ (nuclear factor $\mathrm{kB}-\mathrm{NF \kappa B}$ ), jądrowy czynnik aktywacji limfocytów (nuclear factor of activated $T$ cells - NFAT) czy drogę MAPK/ERK (mitogen activated protein kinase/ extracellular signal regulated kinases) [15].

Zastosowanie inhibitorów BTK w I linii leczenia MCL u chorych bez mutacji TP53 nie jest jednak oczywiste. Ich dodanie w istotny sposób wydłuża czas wolny do progresji (progression free survival - PFS), co stanowiło pierwszorzędowy punkt końcowy 2 randomizowanych badań klinicznych: PCl-32765MCL3002 (NCL01776840) i ACELY-308 (NCT02972840). W obu z nich nieleczeni wcześniej chorzy z rozpoznaniem MCL ustalonym po 65 . roku życia byli poddawani immunochemioterapii BR (bendamustyną, rytuksymab) w połączeniu z placebo lub inhibitorem BTK, odpowiednio ibrutynibem i akalabrutynibem. Wstępną analizę wyników badania $\mathrm{z}$ ibrutynibem $(N=520)$, do którego rekrutację zakończono ponad 4 lata temu, odroczono już dwukrotnie ze względu na brak odpowiedniej liczby zdarzeń. Jeżeli w grupie kontrolnej (leczonej bez inhibitora BTK) częstość wznów/oporności była taka, jak zakładano, oznaczało to istotnie lepsze wyniki w grupie badanej. W aktualnie rekrutującym badaniu $z$ akalabrutynibem (ACE-LY-308) bierze udział 5 polskich ośrodków. Na zmianę standardów praktyki klinicznej mogłoby mieć jednak wpływ jedynie wydłużenie przeżycia całkowitego (overall survival - OS) lub poprawa PFS w porównaniu z czasem bez progresji po łącznie stosowanej immunochemioterapii I linii z następową monoterapią z inhibitorem BTK.

U młodszych chorych Europejska Grupa Badawcza Chłoniaka z Komórek Płaszcza (European MCL Network - EMCLN) prowadzi randomizowane, trójramienne badanie TRIANGLE (NCT02858258), porównujące skuteczność klasycznej immunochemioterapii R-CHOP/R-DHAP + ASCT (grupa kontrolna) z 2 kohortami leczonymi z ibrutynibem (R-CHOP+ibrutynib /R-DHAP + ASCT + leczenie podtrzymujące $z$ ibrutynibem oraz R-CHOP+ibrutynib /R-DHAP + leczenie podtrzymujące $z$ ibrutynibem).

Alternatywną propozycją, przedstawioną przez MD Anderson Cancer Centre (MDACC), jest badanie WINDOW-1 (NCT02427620). Intensywna immunochemioterapia (np. protokół Nordycki czy R-HyperCVAD/R-MTX-Ara-c) pozwala co prawda na uzyskanie ponad 12-letniej mediany OS, ale za cenę trudnego do zaakceptowania zwiększenia częstości występowania zespołów mielodysplastycznych (myelodysplastic syndrome - MDS) (odpowiednio 3,1\% i 6,5\%) i wtórnych procesów nowotworowych (ok. 10\%). W MDACC młodszych chorych poddano indukcji (ibrutynibem + rytuksymabem:
2-12 cykli) z konsolidacją R-Hyper-CVAD (jedynie 4 cykle u chorych z CR po indukcji, nie więcej niż 8 cykli u pacjentów z PR). W tym badaniu uzyskano 98\% CR oraz 90 i 82\% 3-letnie PFS odpowiednio u chorych z ki67\% poniżej i ponad 30\% (Wang et al., ICML 2019). W aktualnie rekrutującym badaniu WINDOW-2 w indukcji stosuje się skojarzenie rytuksymabu, ibrutynibu i wenetoklaksu.

Interesującym badaniem I fazy jest ACE-LY-106 (NCT02717624), prowadzone również w polskich ośrodkach. Stanowiło ono wstępną ocenę toksyczności połączenia immunochemioterapii BR z akalabrutynibem; obecnie otwarta jest kohorta, w której ocenia się toksyczność i efektywność skojarzenia rytuksymabu, wenetoklaksu i akalabrutynibu - w obu przypadkach, u chorych w I linii leczenia, wcześniej niepoddanych terapii.

Rola leków immunomodulujących (immunomodulatory drugs IMIDs) u chorych z MCL jest badana już od ponad 10 lat. $U$ chorych wcześniej nieleczonych lenalidomid był dołączany jako element immunochemioterapii indukującej do schematu BR [16]. Aktualnie EMCLN prowadzi randomizowane badanie MCL R2 Elderly (NCT01865110), porównujące skuteczność leczenia podtrzymującego rytuksymabem i lenalidomidem, u chorych wcześniej poddanych indukcyjnej immunochemioterapii. W badaniach I fazy oceniano również możliwość połączenia IMIDs z ibrutynibem czy wenetoklaksem.

W nawrotowym/opornym MCL zastosowanie terapii celowanej jest standardem postępowania; immunochemioterapię można rozważyć jedynie w razie wznów późnych lub niedostępności inhibitorów BTK czy lenalidomidu.

Przełomowe badania nad zastosowaniem inhibitorów kinazy Brutona u chorych z R/R MCL, prowadzone były pod kierunkiem Prof. Michaela Wang'a z MDACC. Dwa zaplanowane przez niego badania II fazy: z ibrutynibem (PCYC-1104-CA, NCT01236391) [17] i akalabrutynibem (ACE-LY-004, NCT02213926) [18] stały się podstawą ich rejestracji przez amerykańską Agencję Żywności i Leków (Food and Drug Administration - FDA). Pomimo niemal identycznych kryteriów włączenia (R/R MCL, potwierdzona ekspresją cykliny D1, stan czynnościowy wg ECOG $\leq 2$ ) grupy włączonych pacjentów były zupełnie nieporównywalne. Badanie z ibrutynibem rozpoczęto w 2011 roku, gdy dopiero potwierdzano kliniczną skuteczność inhibitorów BTK. Badanie z akalabrutynibem w 2014 roku, gdy ich rola w leczeniu MCL była już udowodniona. Jest więc naturalne, że w pierwszym badaniu było więcej chorych o gorszym rokowaniu (średnia liczba wcześniejszych linii leczenia - 3, chorzy z pośrednim i wysokim MIPI - 86\%, pacjenci z opornością na pierwszą linię leczenia - 45\%). Stąd nie możemy porównywać wyników, a w szczególności odsetków odpowiedzi na leczenie czy mediany PFS (Tab. I) [19].

Można natomiast, a nawet należy, porównywać efekty działań niepożądanych (Tab. II). To szczególnie ważny aspekt, zwłaszcza że przy dłuższym stosowaniu 10-20\% chorych leczonych ibrutynibem w badaniach klinicznych i nawet do $40 \%$ chorych leczonych poza badaniami przerywa jego stosowanie ze względu na złą tolerancję $[20,21]$. Podczas leczenia ibrutynibem ze szczególną uwagą należy monitorować chorych ze skazą krwotoczną, zaburzeniami rytmu serca lub tych, którzy muszą stosować na stałe leki przeciwzakrzepowe. 
Tabela I. Badania rejestracyjne inhibitorów kinazy Brutona w nawrotowym/opornym MCL [19] Table I. Registration trials of Bruton's kinase inhibitors in relapsed/refractory MCL [19]

\begin{tabular}{|c|c|c|}
\hline & PCYC-1104-CA & ACE-LY-004 \\
\hline \multirow[t]{2}{*}{ Inhibitor kinazy Brutona } & Ibrutynib & Akalabrutynib \\
\hline & $560 \mathrm{mg} /$ dobę & $2 \times 100 \mathrm{mg} /$ dobę \\
\hline Liczba poprzednich linii leczenia & $3(1-5)$ & $2(1-5)$ \\
\hline Przebyte ASCT & $11 \%$ & $18 \%$ \\
\hline procentowa ilość chorych średniego i wysokiego ryzyka wg MIPI & $86 \%$ & $60 \%$ \\
\hline Choroba oporna & $45 \%$ & $24 \%$ \\
\hline Choroba masywna $>5 \mathrm{i}>10 \mathrm{~cm}$ & $39 \%$ i $8 \%$ odpowiednio & $37 \%$ i $8 \%$ odpowiednio \\
\hline Pierwszorzędowy punkt końcowy - & ORR-68\% & ORR-81\% \\
\hline \multirow[t]{2}{*}{ ORR } & CR-21\% & CR-40\% \\
\hline & PR-47\% & PR-41\% \\
\hline \multirow[t]{2}{*}{ Mediana czasu do pierwszej odpowiedzi na leczenie (miesiące) } & 1,9 & 1,9 \\
\hline & (zakres 1,4-13,7) & (zakres 1,5-4,4) \\
\hline \multirow[t]{2}{*}{ Mediana czasu do CR (miesiące) } & 5,5 & 3,4 \\
\hline & (zakres $1,7-24,7$ ) & (zakres $1,9-5,5)$ \\
\hline Czas odpowiedzi (DOR) & mediana $17,5 \mathrm{~m}$-ca & $72 \%$ w $12, \mathrm{~m}-\mathrm{cu}$ \\
\hline Czas wolny do progresji (PFS) & mediana 13,9 m-ca & $67 \%$ w $12, \mathrm{~m}-\mathrm{cu}$ \\
\hline Czas całkowitego przeżycia (OS) & $58 \%$ w $18, \mathrm{~m}-\mathrm{cu}$ & $87 \%$ w $12, m-c u$ \\
\hline
\end{tabular}

ASCT - autologiczne przeszczepienie komórek macierzystych, CR - całkowita remisja, DOR - czas odpowiedzi na leczenie, MIPI - międzynarodowy wskaźnik rokowniczy MCL, ORR odsetek odpowiedzi na leczenie, OS - całkowite przeżycie, PFS - czas wolny do progresji, PR - częściowa odpowiedź

Tabela II. Porównanie zdarzeń niepożądanych w badaniach rejestracyjnych inhibitorów kinazy Brutona w nawrotowym/opornym MCL [19] Table II. Comparison of adverse events in registration trials of Bruton's kinase inhibitors in relapse/refractory MCL [19]

\begin{tabular}{|c|c|c|}
\hline & PCYC-1104-CA & ACE-LY-004 \\
\hline \multicolumn{3}{|l|}{ Hematologiczne zdarzenia niepożądane: ogółem/stopnia 3-4 (\%): } \\
\hline Neutropenia & $17 / 16$ & $14 / 14$ \\
\hline Anemia & $11 / 10$ & $15 / 11$ \\
\hline Małopłytkowość & $13 / 11$ & $<5 \%$ \\
\hline Najczęstsze zdarzenia niepożądane ogółem/stopnia 3-4 (\%): & 0 & $38 / 2$ \\
\hline Ból głowy & $53 / 6$ & $31 / 3$ \\
\hline Biegunka & $49 / 5$ & $27 / 1$ \\
\hline Zmęczenie & $17 / 0$ & $21 / 1$ \\
\hline Bóle mięśni & $33 / 1$ & $18 / 1$ \\
\hline \multicolumn{3}{|l|}{ Nudności } \\
\hline Szczególne zdarzenia niepożądane ogółem/stopnia 3-4 (\%) & $7 / 6$ & $7 / 6$ \\
\hline Zapalenie płuc & $7 / 6$ & $0 / 0$ \\
\hline Migotanie przedsionków & $41 / 6$ & $31 / 1$ \\
\hline \multicolumn{3}{|l|}{ Powikłania krwotoczne } \\
\hline $\begin{array}{l}\text { Liczba chorych, którzy przerwali leczenie } \\
\text { z powodu zdarzeń niepożądanych (\%) }\end{array}$ & 11 & 6 \\
\hline
\end{tabular}


U chorych z R/R MCL ostatecznym potwierdzeniem skuteczności ibrutynibu, było randomizowane badanie III fazy, porównujące go z temsirolimusem [22].

Aktualnie u chorych z R/R MCL toczą się badania nad skojarzeniem inhibitorów BTK z innymi lekami, tzw. „doublets” i „triplets”. W Polsce jest prowadzone randomizowane badanie III fazy SYMPATICO (NCT03112174), porównujące w R/R MCL skuteczność ibrutynibu z ibrutynibem w skojarzeniu z wenetoklaksem. Planowane są kolejne. Niestety udział $w$ badaniach klinicznych pozostaje od lat jedyną szansą na leczenie chorych zgodnie ze standardem, Polska jest ostatnim krajem w Europie, w którym inhibitory BTK nie są w MCL refundowane.

Rokowanie pacjentów z opornością na ibrutynib jest niepomyślne, a mediana OS nie przekracza 6 miesięcy [23]. Mechanizmy pierwotnej oporności są wielorakie, za najczęstsze uważa się alternatywne drogi aktywacji czynnika transkrypcyjnego NFkB, modyfikacje epigenetyczne czy mutacje p53. Pacjentów próbuje się leczyć w sposób skojarzony, np. inhibitorem BTH, inhibitorem kinazy fosfatydyloinozytolu i inhibitorem CDK4/6. Dobre odpowiedzi obserwowaliśmy po skojarzeniu tafasitamabu (monoklonalnego przeciwciała anty-CD19) z idelalisibem czy wenetoklaksem [24]. Pojawienie się oporności w trakcie stosowania ibrutynibu ma w części przypadków związek z substytucją cysteiny przez serynę w C481. Uniemożliwia to wiązanie się inhibitorów BTK I generacji, w tym leków selektywnych, takich jak akalabrutynib czy zanubrutynib, a przełamanie oporności jest prawdopodobnie możliwe przy użyciu inhibitorów BTK II generacji, np. Loxo-305 czy vacabrutynib. Leki te są dostępne wyłącznie w ośrodkach prowadzących badania kliniczne.

Kolejną grupę stanowią leki immunomodulujące, choć pozostają w cieniu inhibitorów kinaz. Lenalidomid w monoterapii jest zarejestrowanym lekiem u chorych $\mathrm{z}$ R/R MCL na podstawie wyników wieloośrodkowego badania III fazy CC-5013MCL-002 (NCT00875667), w którym okazał się bardziej skuteczny od dowolnej, wybranej przez badacza alternatywy [25]. Chociaż odpowiedzi na lenalidomid są w porównaniu z ibrutynibem mniej spektakularne, a mediana PFS wynosi 8,6 miesiąca, u 1 chorego na 4 możemy spodziewać się długotrwałych odpowiedzi. Lenalidomid nie działa bezpośrednio na komórki chłoniaka, stymuluje natomiast do działania limfocyty T, przez co trudniej dochodzi do oporności na leczenie. Podejmowano wiele prób skojarzania lenalidomidu $z$ innymi lekami: w badaniu PHILEMON (NLG-MCL6, NCT02460276), prowadzonym przez grupę nordycką, gdzie stosowano lenalidomid $\mathrm{z}$ rytuksymabem i ibrutynibem, mediana PFS nie została osiągnięta po 17 miesiącach obserwacji [26]. Szczegółowe omówienie tych badań przekracza jednak ramy tego opracowania.

U młodszych pacjentów z R/R MCL po ASCT wyniki allogenicznego przeszczepienia komórek hemopoetycznych (allogeneic stem cell transplantation - allo-SCT) pozwalają na uzyskanie mediany PFS trwającej 30 i więcej miesięcy [27, 28]. Jest to dla nas cenna wskazówka, zwłaszcza przy znikomej dostępności nowych metod leczenia i wysokiej klasy ośrodkach przeszczepiania szpiku.

W ciągu ostatnich lat obserwujemy niezwykle dynamiczny rozwój nowych terapii dla chorych z MCL, ze szczególnym wyróżnieniem inhibitorów BTK, stanowiących przełom, głównie w leczeniu chorych z postaciami opornymi i nawrotowymi. Dalszy rozwój nowych terapii może zrewolucjonizować wyniki leczenia u chorych z MCL. Obecnie w czołówce badań klinicznych znajdują się, oprócz inhibitorów punktów kontrolnych, terapie limfocytami T (CAR T-cells) oraz przeciwciała bispecyficzne (BITE). Terapie komórkami CAR T, opracowane w celu bezpośredniego przezwyciężenia niedoborów odpowiedzi limfocytów $\mathrm{T}$, stanowią największą nadzieję w leczeniu opornych postaci MCL. Cząsteczki BITE, które starają się również zaangażować i bezpośrednio aktywować cytotoksyczną moc limfocytów T po interakcji z antygenem nowotworowym, wykazują również zachęcającą skuteczność w leczeniu chorych z rozpoznaniem MCL.

\section{Wkład autorów/ Authors' contributions}

WJ $-50 \%$

MD-D $-50 \%$

\section{Konflikt interesu/ Conflict of interest}

Nie występuje.

\section{Finansowanie/ Financial support}

Nie występuje.

\section{Etyka/Ethics}

Treści przedstawione w artykule są zgodne z zasadami Deklaracji Helsińskiej, dyrektywami EU oraz ujednoliconymi wymaganiami dla czasopism biomedycznych.

\section{Piśmiennictwo}

References

[1] Martin P, Ghione P, Dreyling M. Mantle cell lymphoma - Current standards of care and future directions. Cancer Treat Rev 2017;58:5160.

[2] Vose JM. Mantle cell lymphoma: 2017 update on diagnosis, riskstratification, and clinical management. Am J Hematol 2017;92:80613.

[3] Kahl BS, Dreyling M, Gordon LI, Martin P, Quintanilla-Martinez L, Sotomayor EM. Recent advances and future directions in mantle cell lymphoma research: report of the 2018 mantle cell lymphoma consortium workshop. Leuk Lymphoma 2019;60:1853-65.

[4] Hoster E, Klapper W, Hermine O, et al. Confirmation of the mantlecell lymphoma International Prognostic Index in randomized trials of the European Mantle-Cell Lymphoma Network. J Clin Oncol 2014;32:1338-46.

[5] Hoster E, Rosenwald A, Berger F, et al. Prognostic Value of Ki-67 Index, Cytology, and Growth Pattern in Mantle-Cell Lymphoma: Results 
From Randomized Trials of the European Mantle Cell Lymphoma Network. J Clin Oncol 2016;34:1386-94.

[6] Eskelund CW, Dahl C, Hansen JW, et al. TP53 mutations identify younger mantle cell lymphoma patients who do not benefit from intensive chemoimmunotherapy. Blood 2017;130:1903-10.

[7] Stein L, Bacmeister C, Ylaya K, et al. Immunophenotypic Characterization of Canine Splenic Follicular-Derived B-Cell Lymphoma. Vet Pathol 2019;56:350-7.

[8] Dlugosz-Danecka M, Krawczyk K, Ochrem B, et al. The necessity of post-induction therapy in mantle cell lymphoma patients: $A$ multicenter retrospective real-world analysis by Polish Lymphoma Research Group (PLRG). Postepy Hig Med Dosw 2019;73:303-9.

[9] Eskelund CW, Kolstad A, Jerkeman M, et al. 15-year follow-up of the Second Nordic Mantle Cell Lymphoma trial (MCL2): prolonged remissions without survival plateau. $\mathrm{Br} J$ Haematol 2016;175:410-8.

[10] Bernstein SH, Epner E, Unger JM, et al. A phase II multicenter trial of hyperCVAD MTX/Ara-C and rituximab in patients with previously untreated mantle cell lymphoma; SWOG 0213. Ann Oncol 2013;24:1587-93.

[11] Hermine O, Hoster E, Walewski J, et al. Addition of high-dose cytarabine to immunochemotherapy before autologous stem-cell transplantation in patients aged 65 years or younger with mantle cell lymphoma (MCL Younger): a randomised, open-label, phase 3 trial of the European Mantle Cell Lymphoma Network. Lancet 2016;38:56575.

[12] Robak T, Smolewski P, Robak P, Dreyling M. Mantle cell lymphoma: therapeutic options in transplant-ineligible patients. Leuk Lymphoma 2019:1-13.

[13] Le Gouill S, Thieblemont C, Oberic L, et al. Rituximab Maintenance after Autologous Stem Cell Transplantation Prolongs Survival in Younger Patients with Mantle Cell Lymphoma: Final Results of the Randomized Phase 3 LyMa Trial of the Lysa/Goelams Group. Blood 2016;128:145.

[14] Forstpointner R, Unterhalt M, Dreyling M, et al. Maintenance therapy with rituximab leads to a significant prolongation of response duration after salvage therapy with a combination of rituximab, fludarabine, cyclophosphamide, and mitoxantrone (R-FCM) in patients with recurring and refractory follicular and mantle cell lymphomas: Results of a prospective randomized study of the German Low Grade Lymphoma Study Group (GLSG). Blood 2006;108:4003-8.

[15] Hershkovitz-Rokah O, Pulver D, Lenz G, Shpilberg O. Ibrutinib resistance in mantle cell lymphoma: clinical, molecular and treatment aspects. Br J Haematol 2018;181:306-19.
[16] Albertsson-Lindblad A, Kolstad A, Laurell A, et al. Lenalidomidebendamustine-rituximab in patients older than 65 years with untreated mantle cell lymphoma. Blood 2016;128:1814-20.

[17] Wang ML, Rule S, Martin P, et al. Targeting BTK with ibrutinib in relapsed or refractory mantle-cell lymphoma. N Engl J Med 2013;369(6):507-16.

[18] Wang M, Rule S, Zinzani PL, et al. Acalabrutinib in relapsed or refractory mantle cell lymphoma (ACE-LY-004): a single-arm, multicentre, phase 2 trial. Lancet 2018;391:659-67.

[19] Jurczak W, Dlugosz-Danecka M, Wang M. Acalabrutinib for adults with mantle cell lymphoma. Expert Rev Clin Pharmacol 2019;12:179-87.

[20] Shanafelt TD, Parikh SA, Noseworthy PA, et al. Atrial fibrillation in patients with chronic lymphocytic leukemia (CLL). Leuk Lymphoma 2017;58:1630-9.

[21] Mato AR, Nabhan C, Thompson MC, et al. Toxicities and outcomes of 616 ibrutinib-treated patients in the United States: a real-world analysis. Haematologica 2018;103:874-9.

[22] Dreyling $M$, Jurczak $W$, Jerkeman $M$, et al. Ibrutinib versus temsirolimus in patients with relapsed or refractory mantle-cell lymphoma: an international, randomised, open-label, phase 3 study. Lancet 2016;387:770-8.

[23] Martin P, Maddocks K, Leonard JP, et al. Postibrutinib outcomes in patients with mantle cell lymphoma. Blood 2016;127:1559-63.

[24] Jurczak W, Greil R, Hellmann A, et al. Two-cohort, phase II study in R/R CLL (COSMOS): First preliminary safety and efficacy results of MOR208 treatment in combination with idelalisib in patients who discontinued prior ibrutinib therapy. EHA library 2018;2:214823.

[25] Trneny M, Lamy T, Walewski J, et al. Lenalidomide versus investigator's choice in relapsed or refractory mantle cell lymphoma (MCL-002; SPRINT): a phase 2, randomised, multicentre trial. Lancet Oncol 2016;17:319-31.

[26] Jerkeman M, Eskelund CW, Hutchings M, et al. Ibrutinib, lenalidomide, and rituximab in relapsed or refractory mantle cell lymphoma (PHILEMON): a multicentre, open-label, single-arm, phase 2 trial. Lancet Haematol 2018;5:e109-e16.

[27] Tessoulin B, Ceballos $P$, Chevallier $P$, et al. Allogeneic stem cell transplantation for patients with mantle cell lymphoma who failed autologous stem cell transplantation: a national survey of the SFGMTC. Bone Marrow Transplant 2016;51:1184-90.

[28] Robinson SP, Boumendil A, Finel H, et al. Long-term outcome analysis of reduced-intensity allogeneic stem cell transplantation in patients with mantle cell lymphoma: a retrospective study from the EBMT Lymphoma Working Party. Bone Marrow Transplant 2018;53:617-24. 